\title{
HealthAffairs
}

At the Intersection of Health, Health Care and Policy

Cite this article as:

Maria Alicia Domínguez Ugá and Isabela Soares Santos An Analysis Of Equity In Brazilian Health System Financing Health Affairs, 26, no.4 (2007):1017-1028

doi: 10.1377/hlthaff.26.4.1017

The online version of this article, along with updated information and services, is available at:

http://content.healthaffairs.org/content/26/4/1017.full.html

For Reprints, Links \& Permissions:

http://healthaffairs.org/1340_reprints.php

E-mail Alerts : http://content.healthaffairs.org/subscriptions/etoc.dtl

To Subscribe: http://content.healthaffairs.org/subscriptions/online.shtml

Health Affairs is published monthly by Project HOPE at 7500 Old Georgetown Road, Suite 600, Bethesda, MD 20814-6133. Copyright (C 2007 by Project HOPE - The People-to-People Health Foundation. As provided by United States copyright law (Title 17, U.S. Code), no part of Health Affairs may be reproduced, displayed, or transmitted in any form or by any means, electronic or mechanical, including photocopying or by information storage or retrieval systems, without prior written permission from the Publisher. All rights reserved. 


\section{An Analysis Of Equity In Brazilian Health System Financing}

The Brazilian public-sector health system actually contributes to income inequality because of the presence of out-of-pocket payment.

\section{by Maria Alicia Domínguez Ugá and Isabela Soares Santos}

ABSTRACT: Health care in Brazil is financed from many sources-taxes on income, real property, sales of goods and services, and financial transactions; private insurance purchased by households and firms; and out-of-pocket payments by households. Data on household budgets and tax revenues allow the burden of each source except firms' insurance purchases for their employees to be allocated across deciles of adjusted per capita household income, indicating the progressivity or regressivity of each kind of payment. Overall, financing is approximately neutral, with progressive public finance offsetting regressive payments. This last form of finance pushes some households into poverty. [Health Affairs 26, no. 4 (2007): 1017-1028; 10.1377/hlthaff.26.4.1017]

$\mathrm{T}$ O ASSESS BRAZILIAN HEALTH SYSTEM FINANCING from an equity perspective, this paper analyzes the burden of health-sector financing (by source of financing) across income deciles of the population, as well as the impact of one source of health financing on income distribution and the degree of progressivity of health financing. We base our notion of equitable health-sector financing on the idea of progressivity, where the burden of financing is inversely related to individual income. ${ }^{1}$

\section{The Structure Of Health Financing In Brazil}

Since the 1970s, a large private hospital sector and substantial private health insurance have arisen in Brazil. The current Brazilian public-sector health system was introduced under the new Federal Constitution (1988), which, inspired by the idea of a national health system, created the Sistema Único de Saúde (SUS, or Unified Health System), whose principles are free and universal access to health care, comprehensiveness, and public financing. The SUS functions across Brazil's

Maria Alicia DominguezUgá (domingue@ensp.fiocruz.br) is an economist and senior researcher at the National School of Public Health in Rio de Janeiro, Brazil. She leads the Department of Health Planning and Administration there. Isabela Soares Santos is a social scientist in the Sectoral Development Department of the National Agency for Supplementary Health, Brazil, and a doctoral student at the National School of Public Health. 
three levels of government (central, state, and municipality).

Brazil's constitution allows the existence of a private sector in health, so the Brazilian health system is composed of a mix of the public system and the private sector. The function of private health insurance is called "duplicative" by the Organization for Economic Cooperation and Development (OECD) because the services covered are basically the same services that the SUS provides. ${ }^{2}$ In practice, the statutory system is the public one, and the private sector, which comprises both private voluntary health insurance and private providers, operates alongside the public system. In the private sector, people pay private providers using private health insurance or out-of-pocket payments. Because Brazilian income is concentrated, high-income populations purchase private health insurance more than do those in lower income groups. ${ }^{3}$

Exhibits 1 and 2 show the composition of financing in the Brazilian health sector. The main source of financing is taxes, which support public spending (44 percent of total health spending). One-third (34 percent) of total health spending is out of pocket; spending for private health insurance accounts for 22 percent. The central government finances most public-sector health spending, although its participation has declined in the past two decades. In 2002, federal expenses represented 58 percent of the total, while states and municipalities participated with 20 percent and 22 percent of public-sector health spending, respectively.

At the central level, resources for health come from the social security budget, composed of specific taxes (most of them levied on financial transactions, net profits, and invoicing) for health, social assistance, and pensions. A percentage of this global social security budget is allocated to the health sector, and resources from taxes on financial transactions are mostly allocated to health (this tax was originally created as an earmarked tax for health).

In contrast, states and municipalities do not have specific taxes for health financing. The SUS receives a share of states' and municipalities' total budgets. In 2000, a constitutional amendment established that states and municipalities should allocate 12 percent and 15 percent, respectively, of their revenues to the SUS. Nevertheless, in 2002 only the municipalities reached this goal; the states spent only 9 percent of their revenues on health. It should be noted that these percentages refer to the sum of units in each sphere of government, some of which spent more and others less than these averages on funding the SUS.

The SUS is financed by indirect and direct taxes. Indirect taxes are levied on commercial revenues (Contribution for the Financing of Social Security, or COFINS), industrial output (Brazil Federal Tax, or IPI), sales of merchandise (Tax on Goods and Services, or ICMS), and services (Tax on Services, or ISS). Direct taxes are levied on financial transactions (Provisional Contribution on Financial Transactions, or CPMF), income (Individual Income Tax, or IRPF), urban property (Urban Territorial Tax, or IPTU), and vehicles (Property and Motor Vehicle Tax, or IPVA). 


\section{EXHIBIT 1}

Composition Of Health System Financing (Part 1), Brazil, 2002

\begin{tabular}{|c|c|c|c|}
\hline \multirow[b]{2}{*}{ Revenue and expenditures } & \multicolumn{2}{|c|}{ Tax revenue (millions BR\$) } & \multirow{2}{*}{$\begin{array}{l}\text { Health spending } \\
\text { (millions BR\$) }\end{array}$} \\
\hline & BNDES & SIOPS & \\
\hline \multicolumn{4}{|l|}{ Central } \\
\hline Social security tax (COFINS) & $\$ 50,856.0$ & $-a$ & $\$ 4,455.8$ \\
\hline Tax on profits (CSLL) & $12,375.0$ & $-a$ & $7,579.8$ \\
\hline Tax on transactions (CPMF) & $20,267.0$ & $-a$ & $11,982.4$ \\
\hline Other sources & $193,263.0$ & $-a$ & $5,323.1$ \\
\hline Subtotal & $276,761.0$ & $-a$ & $29,341.1$ \\
\hline \multicolumn{4}{|l|}{ State $^{a}$} \\
\hline ICMS (Total-25\% of transfers to municipalities) & $81,032.5$ & $-c$ & $-c$ \\
\hline ICMS (Total-25\% of transfers to municipalities-FUNDEP) & $-\mathrm{c}$ & $\$ 77,196.9$ & $6,808.8$ \\
\hline IPVA (Total-50\% of transfers to municipalities) & $3,472.4$ & $3,472.4$ & 306.3 \\
\hline Other sources & $15,362.8$ & $-\mathrm{c}$ & $-c$ \\
\hline Transfers from central government & $27,813.4$ & $-a$ & $-a$ \\
\hline FPE $(21.5 \%$ on IR + IPI) & $17,742.6$ & $20,876.3$ & $1,841.3$ \\
\hline IPI & $893.1^{\mathrm{b}}$ & $-a$ & 360.9 \\
\hline IR & $16,849.5^{b}$ & $-a$ & $1,480.4$ \\
\hline Others & $10,070.8$ & $-a$ & $-a$ \\
\hline Less transfers to municipalities & $-7,467.9$ & $-a$ & $-\mathrm{c}$ \\
\hline Subtotal & $120,213.2$ & $114,918.7$ & $10,163.7$ \\
\hline \multicolumn{4}{|l|}{ Local (from own taxes) } \\
\hline ISS & $7,359.9$ & $8,064.0$ & $1,241.9$ \\
\hline IPTU & $6,203.2$ & $6,748.9$ & $1,039.3$ \\
\hline ITBI & $1,331.7$ & $1,457.8$ & 224.5 \\
\hline Others & $7,669.7$ & $-a$ & $-a$ \\
\hline \multicolumn{4}{|l|}{ Transfers } \\
\hline From federal & $23,686.7$ & $-a$ & $-a$ \\
\hline FPM $(22.5 \%$ on IR + IPI) & $18,594.7$ & $19,524.1$ & $3,006.7$ \\
\hline IPI & $3,649.5^{b}$ & $-a$ & 589.3 \\
\hline IR & $14,950.2^{b}$ & $-a$ & $2,417.4$ \\
\hline ITR & 121.5 & $-a$ & $-a$ \\
\hline Others & $4,970.5$ & $-a$ & $-a$ \\
\hline From state & $32,859.4$ & $-a$ & $-a$ \\
\hline IPVA (50\%) & $3,472.4$ & $3,472.4$ & 534.7 \\
\hline ICMS (25\%) & $21,919.1$ & $25,732.3$ & $3,962.8$ \\
\hline Others & $7,467.9$ & $-a$ & $-a$ \\
\hline Subtotal (net revenue) & $79,110.8$ & $71,193.9$ & $10,968.7$ \\
\hline Total public & $476,085.0$ & $-c$ & $50,473.5$ \\
\hline \multicolumn{4}{|l|}{ Summary of financing by source } \\
\hline Public & $-c$ & $-c$ & $50,473.5(43.8 \%)$ \\
\hline Private (health insurance) & $-c$ & $-c$ & $25,063.1(21.7 \%)$ \\
\hline Private (out of pocket) & $-c$ & $-c$ & $39,778.5(34.5 \%)$ \\
\hline Total & $-c$ & $-c$ & $115,315.1(100.0 \%)$ \\
\hline
\end{tabular}

SOURCES: Federal government data calculated by the Institute for Applied Economic Research (IPEA), based on data from the Integrated System of Budget Data (SIDOR) and the Integrated System of Financial Administration (SIAFI); state data estimated by the Information System for the Public Budget in Health (SIOPS) team based on State and Municipal Financial Statements; municipal data reported as of 17 December 2003 to the SIOPS team. Out of pocket: Brazilian Institute of Geography and Statistics (IBGE), National Family Budget Survey (POF), 2002; private health spending, minus health spending on health insurance and claimed as tax write-offs. Private health insurance: National Health Agency (ANS), 2004, data from the Document of Periodic Information from the Private Insurance Companies (DIOPS) for fiscal year 2003; includes financing by individuals and companies.

NOTES: Percentage totals might not add to 100 because of rounding. BNDES is National Bank of Economic and Social Development. SUS is Unified Health System. COFINS is Contribution for the Financing of Social Security. CSLL is Social Contribution on Net Profit. CPMF is Provisional Contribution on Financial Transactions. ICMS is Taxes on Goods and Services. FUNDEP is Research Development Foundation. IPVA is Motor Vehicle Tax. FPE is State Participation Fund. IPI is Brazil Federal Tax. IR is Income Tax. ISS is Tax on Services. IPTU is Urban Territorial Tax. ITBI is Fixed Property Tax. FPM is Municipal Participation Fund.

${ }^{a}$ Data not available from the sources.

${ }^{\mathrm{b}}$ Assuming that the shares of IPI and IR spent on health care are the same.

${ }^{\mathrm{c}}$ Not applicable. 
EXHIBIT 2

Composition Of Health System Financing (Part 2), Brazil, 2002

\begin{tabular}{|c|c|c|c|}
\hline Revenue and expenditures & $\begin{array}{l}\text { Percent of each } \\
\text { tax's contribution } \\
\text { to health spending }\end{array}$ & $\begin{array}{l}\text { Percent of tax- } \\
\text { revenue sources } \\
\text { spent on health }\end{array}$ & $\begin{array}{l}\text { Percent of SUS } \\
\text { budget from various } \\
\text { tax-revenue sources }\end{array}$ \\
\hline \multicolumn{4}{|l|}{ Central } \\
\hline Social security tax (COFINS) & $15.2 \%$ & $8.76 \%$ & $8.83 \%$ \\
\hline Tax on profits (CSLL) & 25.8 & 61.25 & 15.02 \\
\hline Tax on transactions (CPMF) & 40.8 & 59.12 & 23.74 \\
\hline Other sources & 18.1 & 2.75 & 10.55 \\
\hline Subtotal & 100.0 & 10.60 & 58.13 \\
\hline \multicolumn{4}{|l|}{ State } \\
\hline \multicolumn{4}{|l|}{ ICMS (Total-25\% of transfers to municipalities- } \\
\hline FUNDEP) & 67.0 & 6.61 & 13.49 \\
\hline IPVA (Total- $50 \%$ of transfers to municipalities) & 3.0 & 4.41 & 0.61 \\
\hline \multicolumn{4}{|l|}{ Transfers from central government } \\
\hline FPE (21.5\% on IR + IPI) & 18.1 & 10.40 & 3.65 \\
\hline IPI & 3.6 & 1.95 & 0.72 \\
\hline IR & 14.6 & 1.96 & 2.93 \\
\hline Subtotal & 100.0 & 8.92 & 20.14 \\
\hline \multicolumn{4}{|l|}{ Local (from own taxes) } \\
\hline ISS & 11.3 & 16.87 & 2.46 \\
\hline IPTU & 9.5 & 16.75 & 2.06 \\
\hline ITBI & 2.0 & 16.86 & 0.44 \\
\hline Federal transfers-FPM (22.5\% on IR + IPI) & 27.4 & 16.20 & 5.96 \\
\hline IPI & 5.4 & 3.19 & 1.17 \\
\hline IR & 22.0 & 3.20 & 4.79 \\
\hline \multicolumn{4}{|l|}{ State transfers } \\
\hline IPVA $(50 \%)$ & 4.9 & 7.70 & 1.06 \\
\hline ICMS (25\%) & 36.1 & 3.85 & 7.85 \\
\hline Subtotal & 100.0 & 15.40 & 21.73 \\
\hline
\end{tabular}

SOURCES: Federal government data calculated by the Institute for Applied Economic Research (IPEA), based on data from the Integrated System of Budget Data (SIDOR) and the Integrated System of Financial Administration (SIAFI); state data estimated by the Information System for the Public Budget in Health (SIOPS) team based on State and Municipal Financial Statements; municipal data reported as of 17 December 2003 to the SIOPS team.

NOTES: Percentage totals might not add to 100 because of rounding. BNDES is National Bank of Economic and Social Development. SUS is Unified Health System. COFINS is Contribution for the Financing of Social Security. CSLL is Social Contribution on Net Profit. CPMF is Provisional Contribution on Financial Transactions. ICMS is Taxes on Goods and Services. FUNDEP is Research Development Foundation. IPVA is Motor Vehicle Tax. FPE is State Participation Fund. IPI is Brazil Federal Tax. IR is Income Tax. ISS is Tax on Services. IPTU is Urban Territorial Tax. ITBI is Fixed Property Tax. FPM is Municipal Participation Fund.

\section{Study Data And Methods}

An ideal analysis of health-sector financing in Brazil requires estimates of three health spending flows: (1) government expenditures that finance the national health system (the SUS); (2) families' out-of-pocket spending on health services plus health insurance premiums; and (3) companies' expenditures on taxes that finance the SUS (such as Corporate Income Tax, or IRPJ; Social Contribution on Net Profit, or CSLL; and COFINS) and expenses related to the provision of complementary medical and hospital coverage to employees (either through the purchase of health insurance for their employees and dependents or by providing their own health services or reimbursing employees' health spending). There are no sources of information that estimate the distribution of this last type of spending, so we did not consider it in the equity analysis based on the distribution of the 
burden of health care financing between individuals.

To analyze the impact of health-sector financing on income distribution, we identified sources of public and private financing as well as the distribution of this financing burden across income levels: (1) sources that finance the SUS at the three levels of government-federal (taxes related to the social security budget), state (the main taxes of this level of government and the percentage allocated to health), and local (the principal municipal taxes and the percentage allocated to health); (2) the distribution of the tax burden that finances the SUS, through families' consumption baskets, considering direct and indirect taxes; and (3) the different types of private health spending by families (out-of-pocket payments and private health insurance) and the distribution of the burden of private health spending across income deciles. The data on out-of-pocket spending refer to private payments excluding those for private insurance: namely, medicines, dental treatments, physician appointments, outpatient treatments, hospitalizations and surgical services, ancillary diagnostic and therapeutic services, treatment materials, and other expenses. Total private financing is the sum of private health insurance and out-of-pocket spending.

- Data sources and procedures. The distribution of income and the burden of public and private financing of the Brazilian health system were consolidated on the basis of microdata from the National Family Budget Survey (Pesquisa de Orçamentos Familiares, or POF) of the Brazilian Institute of Geography and Statistics (IBGE), which reports the income and expenses of Brazilian families. ${ }^{4}$ The POF was conducted between July 2002 and August 2003; it includes all socioeconomic strata of the resident Brazilian population and uses 2002 as the reference period. The POF is important for the Brazilian government because it supports the National Accounts. Using the software SAS, data were organized by income decile: Families were arrayed by their per capita income and then classified into deciles.

Because the tax structure did not change from 2001 to 2002, data were calculated on the basis of the estimated tax burden for 2001 by the National Bank of Economic and Social Development (BNDES) team. ${ }^{5}$ Changes in the efficiency of tax collection from 2001 to 2002 might have redistributed the burden among deciles by an unknown but probably very slight amount.

Concerning the taxes that finance the SUS at the central level, data were taken from the Institute for Applied Economic Research (IPEA), while data relating to states' and municipalities' health spending came from the Information System for the Public Budget in Health (SIOPS). ${ }^{6}$ These data were based on the State and Municipal Financial Cash-Balances. Municipal data were reported by 4,770 municipalities, representing 86 percent of municipalities and 93 percent of the country's population.

Data on income, out-of-pocket spending, health insurance spending, and direct tax payments were extracted from the POF microdata, while expenses via indirect taxes that finance the SUS were estimated as explained below. 
For Exhibit 2, we computed the fraction of each tax that finances the SUS. The financing of each tax was weighted and applied to each income decile. For example, for the CPMF, the calculation was as follows: weight of CPMF on family income times the weight of the participation of CPMF on SUS financing relative to the revenue from this tax (59.12 percent, as Exhibit 2 shows).

We used two different procedures to examine direct and indirect taxes. For direct taxes, we attributed to households' spending the share of each direct tax destined to fund the SUS. To estimate indirect taxes, we used the methodology developed by Thiago Pereira and Marcelo Ikeda for BNDES, to identify, from the input-output matrix, the composition of tax burden of each item of household consumption. ${ }^{7}$ Because this was originally done without considering population income, Pereira and Ikeda regenerated the results using data from the POF 2002. The result is how much each family had pay for each tax. After that, we applied the weight of each tax on SUS financing, as mentioned above. ${ }^{8}$

Family spending and income were adjusted by two weights. One is the weight of each family, used in the sample to represent the population. The other is an equalization factor to calculate per capita equivalent values. It is important to correct, on the one hand, for the difference between the number of people in each family (poorer families usually have more members) and, on the other hand, for the difference in the numbers of possible contributors to family income. To adjust for these problems, Adam Wagstaff and Eddy van Doorslaer calculated an average factor using data from European families that transforms family spending and income by an exponential factor of $0.75 .{ }^{9}$ We opted to use this in the Brazilian analyses to make it possible to compare our analyses with others.

\section{Results And Analysis}

Brazilian society is marked by great income inequality. The Gini coefficient measures the inequality of the income distribution; it is defined as a ratio with values between 0 (perfect equality) and $1 .^{10}$ The Brazilian Gini coefficient is 0.5703, one of the highest in the world, which indicates Brazil's enormous income concentration. The wealthiest 10 percent of the population receives 46.1 percent of the per capita family income in Brazil, which is greater than the combined income of the lowest eight deciles. At the other extreme, the poorest 20 percent obtains only 2.9 percent of the country's per capita family income. The poorest half of the population receives only 13.7 percent of this income.

According to POF microdata, spending on Brazil's health system absorbed no less than 9.7 percent of family income in 2002. The burden of health-sector financing and the share of each type of health expense vary considerably by income decile (Exhibit 3). Thus, while health absorbed 10.6 percent of income for the lowest income decile, this percentage dropped to 9.1 percent in the highest decile.

Out-of-pocket payment. Worthy of note is private out-of-pocket spending among the poorest families. This expense (which results not from ex ante choice, as 


\section{EXHIBIT 3}

Composition Of Health Financing And Distribution Of Its Weight On Income, By Type Of Expenditure, According To Per Capita Family Income Decile, Brazil, 2002

\begin{tabular}{|c|c|c|c|c|c|c|c|c|c|c|}
\hline & \multicolumn{10}{|c|}{ Per capita family income decile (from lowest to highest) } \\
\hline & 1 & 2 & 3 & 4 & 5 & 6 & 7 & 8 & 9 & 10 \\
\hline Income (percent) ${ }^{\mathrm{a}}$ & 1.00 & 1.92 & 2.74 & 3.56 & 4.53 & 5.80 & 7.59 & 10.43 & 16.34 & 46.10 \\
\hline \multicolumn{11}{|l|}{ SUS } \\
\hline \multicolumn{11}{|l|}{ Total SUS } \\
\hline Percent $^{a}$ & 0.78 & 1.45 & 2.56 & 4.39 & 4.26 & 6.40 & 8.23 & 10.93 & 16.89 & 44.11 \\
\hline Fraction of income & 3.42 & 3.28 & 4.06 & 5.34 & 4.08 & 4.78 & 4.70 & 4.54 & 4.48 & 4.15 \\
\hline Direct taxes (percent) ${ }^{a}$ & 0.67 & 1.23 & 2.36 & 4.36 & 3.98 & 6.29 & 8.13 & 10.86 & 17.05 & 45.08 \\
\hline Indirect taxes (percent) & 1.32 & 2.50 & 3.53 & 4.53 & 5.59 & 6.89 & 8.70 & 11.24 & 16.16 & 39.53 \\
\hline \multicolumn{11}{|l|}{ Private health insurance } \\
\hline Percent ${ }^{a}$ & 0.28 & 0.32 & 0.78 & 1.22 & 2.77 & 3.15 & 5.09 & 11.42 & 19.94 & 55.03 \\
\hline Fraction of income & 0.43 & 0.25 & 0.44 & 0.53 & 0.94 & 0.83 & 1.03 & 1.68 & 1.88 & 1.84 \\
\hline \multicolumn{11}{|l|}{ Out of pocket } \\
\hline \multicolumn{11}{|l|}{ Total out-of-pocket } \\
\hline Percent $^{a}$ & 1.76 & 2.79 & 3.99 & 5.14 & 6.21 & 7.00 & 9.38 & 12.26 & 14.44 & 37.05 \\
\hline Fraction of income & 6.76 & 5.58 & 5.59 & 5.52 & 5.26 & 4.62 & 4.74 & 4.50 & 3.39 & 3.08 \\
\hline Medicines (percent) ${ }^{a}$ & 2.59 & 3.66 & 5.16 & 6.62 & 7.51 & 8.24 & 10.55 & 13.28 & 14.55 & 27.84 \\
\hline \multicolumn{11}{|l|}{ Total private } \\
\hline Percent ${ }^{a}$ & 1.33 & 2.08 & 3.07 & 4.01 & 5.23 & 5.89 & 8.16 & 12.02 & 16.01 & 42.20 \\
\hline Fraction of income & 7.19 & 5.83 & 6.02 & 6.05 & 6.20 & 5.46 & 5.77 & 6.19 & 5.26 & 4.92 \\
\hline \multicolumn{11}{|l|}{ Total health financing } \\
\hline Percent ${ }^{a}$ & 1.09 & 1.80 & 2.84 & 4.18 & 4.79 & 6.12 & 8.19 & 11.53 & 16.41 & 43.05 \\
\hline Fraction of income & 10.61 & 9.11 & 10.08 & 11.39 & 10.28 & 10.24 & 10.48 & 10.73 & 9.75 & 9.07 \\
\hline
\end{tabular}

SOURCE: National Family Budget Survey (POF 2002) of the Brazilian Institute of Geography and Statistics (IBGE).

NOTES: Totals might not add to 100 because of rounding. SUS is Unified Health System.

a Percentage of total national income, taxes, or spending in each category accounted for by members of the income decile.

with insurance, but rather from ex post need) represented 6.8 percent of family income in the lowest decile, and its share was inversely proportional to income; it accounted for only 3.1 percent of income in the highest decile (Exhibit 3).

Exhibit 4 shows the percentage breakdown of out-of-pocket spending by item and population. For all income deciles, medicines were the main out-of-pocket expense in 2002. However, the drug share rises as population income falls. In the lowest decile, drugs absorbed 82.5 percent of their out-of-pocket spending, while the highest income segment allocated 42 percent of their out-of-pocket spending for drugs.

Spending on medicines is extremely regressive. Exhibit 3 shows that the poorest decile, with only 1.0 percent of the income, absorbed 2.6 percent of the burden of this expense; the wealthiest decile, with 46.1 percent of the income, accounted for only 27.8 percent of this expense.

Conversely, spending for dental care is relevant only in the upper income deciles. Evidently, the issue here is one of differential access, as determined by budget constraints. Only upper-income people can afford private dental services. Despite dental services being formally covered by the SUS, the population covered for 


\section{EXHIBIT 4}

Distribution Of Direct Family Per Capita Private Out-Of-Pocket Spending On Health, By Income Decile, Brazil, 2002

\begin{tabular}{|c|c|c|c|c|c|c|c|c|c|c|}
\hline \multirow{2}{*}{$\begin{array}{l}\text { Health spending } \\
\text { item }\end{array}$} & \multicolumn{10}{|c|}{ Family per capita income decile (from lowest to highest) } \\
\hline & 1 & 2 & 3 & 4 & 5 & 6 & 7 & 8 & 9 & 10 \\
\hline Medicines & $82.5 \%$ & $73.4 \%$ & $72.4 \%$ & $72.1 \%$ & $67.6 \%$ & $65.8 \%$ & $62.9 \%$ & $60.6 \%$ & $56.4 \%$ & $42.0 \%$ \\
\hline Dental treatment & 2.2 & 5.4 & 7.3 & 6.7 & 8.6 & 8.8 & 12.3 & 14.4 & 14.8 & 17.7 \\
\hline Physician appointments & 5.3 & 6.5 & 6.2 & 6.2 & 7.3 & 8.3 & 7.8 & 8.5 & 8.9 & 6.0 \\
\hline \multirow{3}{*}{$\begin{array}{l}\text { Outpatient treatment } \\
\text { Hospitalization and } \\
\text { surgical services } \\
\text { Ancillary diagnostic and } \\
\text { therapeutic tests } \\
\text { and services }\end{array}$} & 0.5 & 0.7 & 0.7 & 0.5 & 1.2 & 0.8 & 0.8 & 0.9 & 1.6 & 3.4 \\
\hline & 0.5 & 1.4 & 2.1 & 3.3 & 3.4 & 3.9 & 4.4 & 2.5 & 4.4 & 16.9 \\
\hline & 3.5 & 4.3 & 4.8 & 5.0 & 4.3 & 5.2 & 5.0 & 4.8 & 5.3 & 3.2 \\
\hline \multirow{2}{*}{$\begin{array}{l}\text { Treatment materials } \\
\text { Other health care } \\
\text { expenses }\end{array}$} & 3.3 & 6.2 & 5.5 & 4.6 & 6.6 & 6.0 & 5.7 & 7.2 & 7.4 & 9.3 \\
\hline & 2.3 & 2.1 & 1.0 & 1.6 & 1.1 & 1.1 & 1.4 & 1.0 & 1.2 & 1.5 \\
\hline
\end{tabular}

SOURCE: National Family Budget Survey (POF2002) of the Brazilian Institute of Geography and Statistics (IBGE).

NOTES: These data do not include payments for private health insurance. Totals might not add to 100 because of rounding.

these services was very low until 2002, when they were included in the basket of services offered by the Family Health Care Program, a public program that has improved access to primary health care in Brazil. ${ }^{11}$

Also noteworthy is the nearly constant share of spending for ancillary diagnostic and therapeutic tests and services in all income deciles, especially between the lowest and highest income groups. The wealthiest and the poorest are comparatively well protected from this expense. Low expense in the richest decile probably occurs because it is covered by supplementary health schemes; the poorest likely cannot afford this kind of health service.

When one considers out-of-pocket spending as a whole, the regressivity is even greater. Thus, while the poorest decile (with 1.0 percent of the country's income) accounted for 1.8 percent of out-of-pocket spending, the wealthiest decile (with 46.1 percent of the country's income) accounted for only 37.0 percent of this spending. In income deciles $1-8$, the share of out-of-pocket spending exceeded the share of the country's income, which confirms the regressivity of out-of-pocket spending, as determined fundamentally by the need to acquire health goods and services rather than by families' capacity to pay for them. It should be noted that out-of-pocket spending could be related to inequitable situations of access-at least when private care presents an alternative to some problems encountered in using the public system, such as long waiting times-while the lowest income groups are less likely to use private facilities, because they cannot afford them.

It is interesting to analyze the effect of out-of-pocket health spending on the incomes of the poorest classes in Brazilian society. Assuming that half of the Brazilian minimum wage is the least a person needs to not be considered extremely poor, 19.3 percent of the Brazilian population is below this extreme poverty line. If out- 
of-pocket spending is subtracted from income, the indigent constitute 20.7 percent of Brazil's population, an increase of 1.4 percentage points, which might not seem large but illustrates the effect of out-of-pocket health payments on population income. This is notable because it shows that to some degree, Brazilian health policy increases poverty, as a result of the inequity of out-of-pocket spending.

- Private health insurance. Spending on private health insurance exceeds the share of income only in the three wealthiest income deciles. They have the capacity to purchase health plans and also belong mostly to the formal labor market, which gives them access to private coverage through employer-group plans. This spending is apparently (and only apparently) progressive: The percentage share of the lowest seven deciles is far less than proportional to individuals' incomes, while for the three richer deciles, it is more than proportional to income (Exhibit 3).

This seeming progressivity is in reality a function of the fact that the low spending by lower income groups is a result of their exclusion from private health insurance, as shown by Ligia Bahia and colleagues and by Sílvia Porto and colleagues. ${ }^{12}$ Clearly, when the poor are excluded, they do not pay, but then they do not get the benefits, either. The low percentages of spending on private health insurance in the lowest income deciles thus reflect Brazil's maldistribution of income. However, an analysis of progressivity (or regressivity) does not apply to private health insurance, because it deals with access to an exclusionary system, conditioned on individuals' capacity to pay or their inclusion in the formal labor market, or both.

- Public financing of the SUS. For financing the public system through payment of taxes and social contributions, the lower income deciles contribute less than proportionally to their income: The lowest decile (with 1.0 percent of the country's income) pays only 0.8 percent of these tax payments; likewise, the secondlowest decile (with 1.9 percent of the income) pays 1.4 percent of the taxes; meanwhile, the third decile (with 2.7 percent of the income) accounts for 2.6 percent of the taxes paid. This might indicate a progressive tax structure. ${ }^{13}$ However, the highest decile (with 46.1 percent of the country's income) is responsible for only 44.1 percent of the tax payments; this decreases the degree of progressivity of public financing. In deciles 4-9, the income-to-payments ratio is very close to proportional. Thus, financing of the SUS as a whole is progressive in relation to the treatment of the poorest three deciles, regressive in relation to the wealthiest decile, and proportional in the rest of the population.

Direct taxes in Brazil (levied on income, urban buildings and land, vehicle ownership, and financial transactions) are quite progressive, principally in the distribution of the burden between deciles 1-9. They penalize the wealthiest segments (deciles 6-9) more than proportionally to income (Exhibit 3). However, the highest decile pays these taxes slightly less than proportionally to its income: It accounts for 45.1 percent of direct tax payments (with 46.10 percent of the income).

The indirect taxes financing the Brazilian health system are levied on company commercial revenues, industrial output, and sales of merchandise and services. 
Their regressivity is obvious: The poorest decile (with only 1.0 percent of the country's income) covers 1.3 percent of these tax payments, while the wealthiest covers 39.5 percent (less than its income share, as stated above). These indirect taxes, which are passed on to consumers through prices, are always regressive. Since the poorer strata spend their income entirely — or preponderantly-on consumption (while saving little or nothing), unlike the wealthier strata, a larger share of the income in the poorer strata is absorbed by these taxes, as expected.

\section{Concluding Comments}

Although Brazil's national health system model, the SUS, is defined constitutionally as providing universal and comprehensive access to health care, the structure of health spending in Brazil is quite different from that of national health systems in richer welfare states in relation to the state's participation in health-sector financing. ${ }^{14}$ Brazil's financing structure reflects the low level of public financing for health-3.8 percent of Brazil's gross domestic product (GDP) - and the importance of the private sector to the entire system. ${ }^{15}$

While health spending in the United Kingdom, Denmark, and Sweden are 80 percent or more public and financed predominantly by general taxes, in Brazil the public sector contributes only 44 percent to national health spending and is thus comparable to that of the United States. However, the composition of healthsector financing in Brazil is even more unfair than in the United States, because the majority of the private share consists of out-of-pocket spending, some of which is catastrophic in nature. The result is a difference in payments by people with similar incomes - in other words, horizontal inequity.

The analysis of vertical equity, which considers the distribution of health-sector financing among Brazilians at different income levels, also shows that (with the exception of private health insurance financing) the burden of financing penalizes more than proportionally the poorest rather than the richest segments of the population; this is particularly the case for indirect taxes and out-of-pocket spending.

An alarming finding of this study is both the amount of spending on drugs and its distribution. Drug spending represents the largest component of out-ofpocket payments for all income deciles. In addition, drug spending as a share of income rises as population income declines. Therefore, medicines definitely demand public policy action to protect the lowest-income populations from this expense whenever it is not supported by the public system.

The analysis of private financing for ancillary diagnostic and therapeutic services shows that it penalizes the entire population, mostly those in neither the lowest nor the highest income deciles, possibly because the latter are covered by supplementary health schemes and the former spend their money on other types of health services.

A different logic is evident in the distribution of private health insurance payments, which are apparently progressive, but this is because the reduced insur- 
ance spending among lower-income strata basically expresses how rarely they are included in such insurance, because of their low incomes. Given the extremely high income concentration of Brazilian society, no other behavior would be possible; the low-income population could never have access to a supplementary system (in relation to the SUS) unless it was financed by employers, and it is mainly the middle-income segments of the population that have formal employment.

The SUS is financed through payment of taxes and social contributions, so that the degree of equity in financing the public-sector health system is the same as that of the taxes that finance it. Our results show that the lower income deciles contribute less than proportionally to their income, which indicates a slightly progressive tax structure. However, since the highest decile (with 46.1 percent of the country's income) contributes slightly less than proportionally to its income, the degree of progressivity in the taxes that finance the SUS decreases at high incomes. Furthermore, it should be noted that the study did not consider the "negative taxes" represented by income tax deductions related to private health spending, which are, in fact, strong subsidies from the state toward those who can afford private facilities and health insurance schemes.

The financing of the entire health system is slightly regressive as a result of the following: on the one hand, the presence of progressive direct taxes, such as income and vehicle taxes, as well as the presence of private insurance, which appears to be progressive (although it is not); and, on the other hand, the role of heavily regressive indirect taxes, like the value-added tax on merchandise, the services tax, and the contribution to social security financing, which is levied on companies' invoicing, as well as the weight of out-of-pocket spending (heavily regressive). ${ }^{16}$ These factors outweigh the progressivity in financing the system as a whole.

I N A SOCIETY AS UNEQUAL AS BRAZIL's, which has a Gini coefficient of 0.5703 , to have proportional financing of the national health system (SUS) is highly questionable from the perspective of social justice. On the contrary, it is necessary to establish the basis for financing the SUS - that is, a tax system-that is explicitly progressive, to counteract the country's extreme income concentration. Furthermore, the participation of public financing in total health spending should greatly increase, to reduce the importance of out-of-pocket payments.

The authors gratefully acknowledge the U.K. Department for International Development (DFID/UK) for financing, and Eddy van Doorslaer and Tim Ensor for their participation as consultants in the development of the study from which this paper is derived. 


\section{NOTES}

1. A. Wagstaff, "Measuring Equity in Health Care Financing: Reflection on and Alternatives to the WHO's Fairness of Financing Index" (Washington: Development Research Group and Human Development Network, World Bank, 2001).

2. Organization for Economic Cooperation and Development, "Proposal for a Taxonomy of Health Insurance," OECD Study on Private Health Insurance, OECD Health Project, June 2004, http://www.oecd.org/ dataoecd/24/52/31916207.pdf (accessed 26 April 2007).

3. S. Porto, I.S. Santos, and M.A.D. Ugá, "A utilização de serviços de saúde por sistema de financiamento," Revista Ciência e Saúde Coletiva 1l, no. 4 (2006): 895-910.

4. Brazilian Institute of Geography and Statistics, "Pesquisa de Orçamentos Familiares (POF), 2002-2003," 2005, http:/www.ibge.gov.br/home/estatistica/populacao/condicaodevida/pof/2002/default.shtm (accessed 26 April 2007).

5. J.R. Afonso, R.F. Silveira, and E.A. Araújo, “Carga tributária global: estimativa para 2001," INFORME-SE no. 40, May 2002, http://www.bndes.gov.br/conhecimento/informeSF/inf_40.pdf (accessed 26 April 2007).

6. See the home page of the Information System for the Public Budget in Health (SIOPS), Ministry of Health, Brazil (in Portuguese), http://siops.datasus.gov.br.

7. T.R. Pereira and M. Ikeda, "Custo Brasil—-mensurando a cumulatividade das contribuições: uma proposta metodológica," INFORME-SE no. 27, June 2001, http://www.bndes.gov.br/conhecimento/informeSF/inf_27 .pdf (accessed 26 April 2007).

8. For more details, see M.A.D. Ugá and I.S. Santos, "Uma análise da equidade do financiamento do sistema de saúde Brasileiro," March 2005, available at http://www.ans.gov.br/portal/site/Biblioteca/biblioteca topico_17702.asp (accessed 26 April 2007)

9. Wagstaff, "Measuring Equity in Health Care Financing."

10. R. Hoffmann, Distribuição de renda: medidas de desigualdade epobreza (São Paulo: Editora da Universidade de São Paulo, 1998).

11. Porto et al., "A utilização de serviços de saúde por sistema de financiamento."

12. Ibid.; and L. Bahia et al., "O mercado de planos e seguros de saúde no Brasil: uma abordagem exploratória sobre a estratificação das demandas segundo a PNAD 2003," Revista Ciência e Saúde Coletiva ll, no. 4 (2006): 951-966.

13. M.A.D. Ugá and I.S. Santos, "Uma análise da progressividade do financiamento do Sistema Único de Saúde (SUS)," Cadernos de Saúde Pública 22, no. 8 (2006): 1597-1610.

14. G. Esping-Andersen, Three Worlds of Welfare Capitalism (Cambridge, U.K.: Policy Press, 1990).

15. Ugá and Santos, "Uma análise da equidade do financiamento do sistema de saúde Brasileiro."

16. Ugá and Santos, "Uma análise da progressividade do financiamento do Sistema Único de Saúde (SUS)." 